\title{
DAYCENT National-Scale Simulations of Nitrous Oxide Emissions from Cropped Soils in the United States
}

\author{
S. J. Del Grosso,* W. J. Parton, A. R. Mosier, M. K. Walsh, D. S. Ojima, and P. E. Thornton
}

\begin{abstract}
Until recently, Intergovernmental Panel on Climate Change (IPCC) emission factor methodology, based on simple empirical relationships, has been used to estimate carbon (C) and nitrogen (N) fluxes for regional and national inventories. However, the 2005 USEPA greenhouse gas inventory includes estimates of $\mathrm{N}_{2} \mathrm{O}$ emissions from cultivated soils derived from simulations using DAYCENT, a process-based biogeochemical model. DAYCENT simulated major U.S. crops at county-level resolution and IPCC emission factor methodology was used to estimate emissions for the approximately $14 \%$ of cropped land not simulated by DAYCENT. The methodology used to combine DAYCENT simulations and IPCC methodology to estimate direct and indirect $\mathrm{N}_{2} \mathrm{O}$ emissions is described in detail. Nitrous oxide emissions from simulations of presettlement native vegetation were subtracted from cropped soil $\mathrm{N}_{2} \mathrm{O}$ to isolate anthropogenic emissions. Meteorological data required to drive DAYCENT were acquired from DAYMET, an algorithm that uses weather station data and accounts for topography to predict daily temperature and precipitation at $1-\mathrm{km}^{2}$ resolution. Soils data were acquired from the State Soil Geographic Database (STATSGO). Weather data and dominant soil texture class that lie closest to the geographical center of the largest cluster of cropped land in each county were used to drive DAYCENT. Land management information was implemented at the agricultural-economic region level, as defined by the Agricultural Sector Model. Maps of model-simulated county-level crop yields were compared with yields estimated by the USDA for quality control. Combining results from DAYCENT simulations of major crops and IPCC methodology for remaining cropland yielded estimates of approximately 109 and approximately $70 \mathrm{Tg} \mathrm{CO}_{2}$ equivalents for direct and indirect, respectively, mean annual anthropogenic $\mathrm{N}_{2} \mathrm{O}$ emissions for 1990-2003.
\end{abstract}

A GRICULTURAL SOILS are responsible for the majority of anthropogenic nitrous oxide $\left(\mathrm{N}_{2} \mathrm{O}\right)$ emissions (Mosier and Kroeze, 2000). Nitrous oxide is an important greenhouse gas (GHG) because it has approximately 300 times the global warming potential of $\mathrm{CO}_{2}$ on a mass basis (IPCC, 2001), and it also influences ozone chemistry (Crutzen, 1981; Crutzen and Ehhalt, 1977). To address concerns regarding $\mathrm{N}_{2} \mathrm{O}$ and other

S.J. Del Grosso, USDA-ARS-NPA-SPNR, Natural Resources Research Center, 2150 Centre Avenue, Building D, Suite 10, Fort Collins, CO 80526-8119. W.J. Parton and D.S. Ojima, Natural Resource Ecology Laboratory, Colorado State University, Fort Collins, CO 80523. A.R. Mosier, Agricultural and Biological Engineering, University of Florida, PO Box 110570, Gainesville, FL 32611-0570. M.K Walsh, ICF Consulting, 1725 I Street NW, Suite 1000, Washington, DC 20006. P.E. Thornton, Terrestrial Sciences Section, National Center for Atmospheric Research, PO Box 3000, Boulder, CO 80305. Received 29 Apr. 2005. *Corresponding author (delgro@nrel.colostate.edu).

Published in J. Environ. Qual. 35:1451-1460 (2006).

Special Submissions

doi:10.2134/jeq2005.0160

(c) ASA, CSSA, SSSA

677 S. Segoe Rd., Madison, WI 53711 USA
GHGs, signatory countries of the United Nations Framework Convention on Climate Change are required to estimate annual sources and sinks for greenhouse gases. Annual national GHG flux estimates for agriculture and other sectors are included in the Inventory of U.S. Greenhouse Gas Emissions and Sinks: 1990-2003 (USEPA, 2005). Before the 2005 inventory, GHG estimates for the agricultural sector were based entirely on Intergovernmental Panel on Climate Change (IPCC, 1997) emission factor methodology. However, the 2005 inventory includes $\mathrm{N}_{2} \mathrm{O}$ emission estimates generated by the DAYCENT ecosystem model. This paper describes the methodology used to estimate $\mathrm{N}_{2} \mathrm{O}$ emissions from cropped soils at the national scale using a process-based model for major crops and IPCC methodology for other crops during the period 1990-2003.

Nitrous oxide is produced naturally in soils through the microbial processes of nitrification and denitrification (Khalil et al., 2004). Agriculture practices, such as nitrogen $(\mathrm{N})$ amendments (e.g., fertilizer, manure), cultivation, legume cropping, and irrigation, can increase $\mathrm{N}_{2} \mathrm{O}$ production and emissions above background levels. Application of synthetic fertilizer directly increases the pool of mineral $\mathrm{N}$ available for nitrification and denitrification. Cultivation, particularly of soils with high organic matter levels, transfers $\mathrm{N}$ from the immobilized (i.e., organic) to the mineral form and thus also increases $\mathrm{N}$ availability for nitrification. Nitrogen fixed from legume cropping can be transformed and increase the soil mineral $\mathrm{N}$ pool. Irrigation reduces water stress, enhances microbial activity, and contributes to soil anoxia which facilitates denitrification. These and other factors that influence mineral $\mathrm{N}$ supply, plant $\mathrm{N}$ demand, and abiotic soil conditions interact to control $\mathrm{N}_{2} \mathrm{O}$ emissions from soils.

In addition to increasing direct soil $\mathrm{N}_{2} \mathrm{O}$ emissions from enhanced nitrification and denitrification, agricultural practices also tend to increase $\mathrm{N}$ volatilization and $\mathrm{NO}_{3}$ leaching. Volatilized $\mathrm{N}$ that is deposited on soils and leached $\mathrm{NO}_{3}$ that enters aquatic systems contribute to indirect $\mathrm{N}_{2} \mathrm{O}$ emissions. Indirect $\mathrm{N}_{2} \mathrm{O}$ is defined as $\mathrm{N}_{2} \mathrm{O}$ that was emitted from a non-farm source from $\mathrm{N}$ that was transported from a farm in a form other than $\mathrm{N}_{2} \mathrm{O}$. Volatized $\mathrm{N}$ can contribute to indirect $\mathrm{N}_{2} \mathrm{O}$ emissions because a portion of this $\mathrm{N}$ will be deposited on non-farm soils, enter the plant-soil system, and undergo transformations that result in $\mathrm{N}_{2} \mathrm{O}$ emissions. A portion of the $\mathrm{NO}_{3}$ that is leached into aquatic systems can be denitrified and result in $\mathrm{N}_{2} \mathrm{O}$ emissions.

Abbreviations: GHG, greenhouse gas; IPCC, Intergovernmental Panel on Climate Change; NASS, National Agricultural Statistics Service; NPP, net primary production; SOM, soil organic matter; STATSGO, State Soil Geographic Database. 


\section{MATERIALS AND METHODS}

\section{Development of Hybrid Modeling Approach}

A hybrid approach was used because it would be difficult to parameterize and run DAYCENT for all crops grown in the United States. DAYCENT was used to estimate emissions for major crops, and IPCC (1997) guidelines were used for remaining crops and for any crops grown on Histosols (soils of high organic matter content). IPCC (1997) guidelines were also used to estimate the proportion of volatilized and leached/ runoff $\mathrm{N}$ that contributes to indirect $\mathrm{N}_{2} \mathrm{O}$ emissions. DAYCENT has been parameterized to simulate most of the major cropping systems in the United States [corn, Zea mays L.; soybean, Glycine max (L.) Merr.; wheat, Triticum aestivum L.; alfalfa, Medicago sativa L.; hay; other hay; sorghum, Sorghum bicolor (L.) Moench; and cotton, Gossypium hirsutum L.], although formal yield comparisons with observed data have only been conducted with corn, soybean, wheat, and alfalfa hay (Del Grosso et al., 2005). These crops represent approximately $86 \%$ of total cropped land in the United States. IPCC (1997) emission factor methodology was used to estimate emissions from cropped land not simulated by DAYCENT. A primary difference between using IPCC guidelines and a process-based model such as DAYCENT is that the former is activity based; that is, the total amount of $\mathrm{N}$ applied to crops is accounted for but it is not necessary to know the areas of specific crops receiving this $\mathrm{N}$. In contrast, DAYCENT simulations are area and activity based; that is, $\mathrm{N}$ amendments are accounted for but it is also necessary to know the crop-specific areas at whatever resolution the simulations are performed. Approximately $84 \%$ of synthetic $\mathrm{N}$ and $100 \%$ of manure, sewage sludge, and other organic matter (e.g., dried blood, tankage, compost) additions to crops were applied to the major crops simulated by DAYCENT.

\section{DAYCENT Model Overview}

DAYCENT is the daily time-step version of the CENTURY biogeochemical model (Parton et al., 1994). DAYCENT simulates fluxes of carbon (C) and $\mathrm{N}$ among the atmosphere, vegetation, and soil (Del Grosso et al., 2001a; Parton et al., 1998). Key submodels include soil water content and temperature by layer, plant production and allocation of net primary production (NPP), decomposition of litter and soil organic matter, mineralization of nutrients, $\mathrm{N}$ gas emissions from nitrification and denitrification, and $\mathrm{CH}_{4}$ oxidation in non-saturated soils. Flows of $\mathrm{C}$ and $\mathrm{N}$ between the different pools are controlled by the size of the pools, $\mathrm{C}$ to $\mathrm{N}$ ratio and lignin content of material, and abiotic water and temperature controls. The land surface submodel used in DAYCENT simulates soil water content and temperature by horizon (Parton et al., 1998). Plant production is a function of genetic potential, phenology, nutrient availability, water and temperature stress, and solar radiation. The NPP is allocated to plant components (e.g., roots vs. shoots) based on vegetation type, phenology, and water and nutrient stress. Nutrient concentrations of plant components vary within specified limits, depending on vegetation type, and nutrient availability relative to plant demand. Decomposition of litter and soil organic matter (SOM) and nutrient mineralization are functions of substrate availability, substrate quality (lignin \%, C to $\mathrm{N}$ ratio), and water and temperature stress. Nitrogen gas fluxes from nitrification and denitrification are driven by soil $\mathrm{NH}_{4}$ and $\mathrm{NO}_{3}$ concentrations, water content, temperature, texture, and labile $\mathrm{C}$ availability (Parton et al., 2001).

The model operates on a daily time step and inputs are: daily maximum and minimum air temperature and precipitation, surface soil texture class, and land cover-land use data (e.g., vegetation type, cultivation and planting schedules, amount and timing of nutrient amendments). Outputs include: daily $\mathrm{N}$-gas flux $\left(\mathrm{N}_{2} \mathrm{O}, \mathrm{NO}_{x}, \mathrm{~N}_{2}\right), \mathrm{CH}_{4}$ uptake, $\mathrm{CO}_{2}$ flux from heterotrophic soil respiration, actual evapotranspiration, soil $\mathrm{NO}_{3}$, water content, and temperature by horizon, soil $\mathrm{NH}_{4}$ in top $15 \mathrm{~cm}$, $\mathrm{H}_{2} \mathrm{O}$ and $\mathrm{NO}_{3}$ leaching, weekly live biomass, monthly NPP, soil organic $\mathrm{C}$ and $\mathrm{N}$, surface litter, standing dead litter, and other ecosystem parameters. Recent improvements to the model include the ability to schedule management events daily and the option of making crop germination a function of soil temperature and harvest date a function of accumulated growing degree days. In previous versions of DAYCENT, managements events could only be scheduled on a monthly basis and were assumed to occur on the first day (for planting and application of fertilizer) or the last day of the month (for harvesting).

The ability of DAYCENT to simulate NPP, soil organic C, $\mathrm{N}_{2} \mathrm{O}$ emissions, $\mathrm{NO}_{3}$ leaching, and $\mathrm{CH}_{4}$ oxidation has been tested with data from various native and managed systems (Del Grosso et al., 2000b, 2001b, 2002, 2005). Simulated and observed grain yields for major cropping systems in North America agreed well with data at both the site $\left(r^{2}=0.90\right)$ and regional $\left(r^{2}=0.66\right)$ levels (Del Grosso et al., 2005). Nitrous oxide emission data from eight cropped sites and $\mathrm{NO}_{3}$ leaching data from three cropped sites showed reasonable agreement with DAYCENT simulations with $r^{2}$ values of 0.74 and 0.96 for $\mathrm{N}_{2} \mathrm{O}$ and $\mathrm{NO}_{3}$, respectively (Del Grosso et al., 2005).

\section{DAYCENT Model Sensitivity Analysis}

A sensitivity analysis was conducted to investigate how simulated $\mathrm{N}_{2} \mathrm{O}$ emissions respond to systematic variation of model inputs and to increase confidence in model results. A $2 \times 3 \times 6$ factorial design was used involving two climate files (wet and dry), three soil texture classes (clay, loam, and sand), and six fertilizer application levels $(0,50,100,150,200$, and $250 \mathrm{~kg} \mathrm{~N} \mathrm{ha}^{-1}$ ). We ran the model for $10 \mathrm{yr}$ under each cropping scenario and assuming native vegetation, then calculated mean annual simulated $\mathrm{N}_{2} \mathrm{O}$ emissions, $\mathrm{N}$ fixation, and $\mathrm{N}$ inputs from residue. A 3-yr rotation of winter wheat-corn-soy was used to include the most common crops grown in the United States. To be consistent with IPCC methodology, we calculated direct soil DAYCENT $\mathrm{N}_{2} \mathrm{O}$ emission factors by dividing simulated $\mathrm{N}_{2} \mathrm{O}$ emissions by total $\mathrm{N}$ inputs ( $\mathrm{N}$ from fertilizer $+\mathrm{N}$ from fixation $+\mathrm{N}$ from aboveground crop residue). IPCC (1997) methodology is intended to isolate anthropogenic emissions so we subtracted simulated $\mathrm{N}_{2} \mathrm{O}$ losses for native vegetation from $\mathrm{N}_{2} \mathrm{O}$ losses for the six cropping scenarios and assumed that this difference represents anthropogenic emissions.

Similar to data reported from numerous studies (Bouwman et al., 2002a, 2002b), emissions tend to be lower from sandy soils that are well drained than from clay soils that are not well drained (Fig. 1). Interestingly, the mean DAYCENT emission

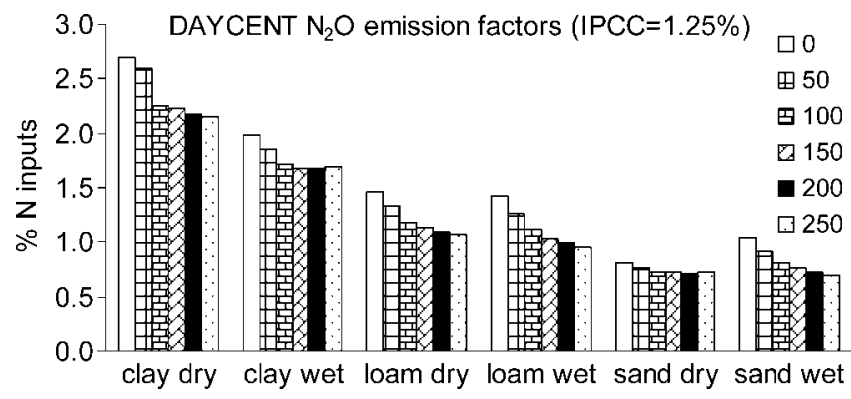

Fig. 1. Sensitivity of calculated DAYCENT $\mathrm{N}_{2} \mathrm{O}$ emissions factors to soil texture class, mean annual precipitation (low $=480 \mathrm{~mm}$, high $=$ $960 \mathrm{~mm})$, and $\mathrm{N}$ fertilizer additions $\left(\mathrm{kg} \mathrm{N} \mathrm{ha}^{-1}\right)$. 
factor for clay soils $(2.1 \%)$ was higher than the IPCC value of $1.25 \%$, while the mean for sandy soils $(0.8 \%)$ was lower than the IPCC value $(1.25 \%)$. For loam soils the DAYCENT mean $(1.2 \%)$ was similar to the IPCC value. In the model, finertextured soils are assumed to have lower gas diffusivity and a larger number of anoxic microsites which facilitate $\mathrm{N}_{2} \mathrm{O}$ losses from denitrification (Del Grosso et al., 2000a). Also, DAYCENT assumes that finer-textured soils contain more organic matter than coarse-textured soils because less $\mathrm{C}$ is respired as $\mathrm{CO}_{2}$ during decomposition of plant residue. Higher soil organic matter is associated with increased $\mathrm{N}_{2} \mathrm{O}$ emissions (Bouwman et al., 2002a, 2002b) because C is a substrate for denitrifying microbes.

Both DAYCENT and data (Bouwman et al., 2002a, 2002b) show a direct relationship between the amount of $\mathrm{N}$ fertilizer added and $\mathrm{N}_{2} \mathrm{O}$ emissions because $\mathrm{N}_{2} \mathrm{O}$ emissions increase as available $\mathrm{N}$ increases. However, DAYCENT results suggest that as a percentage of $\mathrm{N}$ inputs, $\mathrm{N}_{2} \mathrm{O}$ emissions tend to decline as $\mathrm{N}$ fertilizer increases (Fig. 1). This is consistent with data from corn cropping in Tennessee showing that the calculated emission factor for $\mathrm{N}_{2} \mathrm{O}$ emissions from corn decreased as fertilizer additions increased (Thornton and Valente, 1996). Similarly, data from irrigated corn cropping in Colorado showed lower calculated $\mathrm{N}_{2} \mathrm{O}$ emission factors as $\mathrm{N}$ fertilizer increased (Mosier et al., 2006). The trend toward higher emission factors as $\mathrm{N}$ fertilizer decreases is at least partially due to dividing $\mathrm{N}_{2} \mathrm{O}$ emissions by a smaller number (fertilizer $\mathrm{N}+$ residue $\mathrm{N}+$ fixed $\mathrm{N}$ ) that does not account for all $\mathrm{N}$ inputs. For example, even when no $\mathrm{N}$ fertilizer is added, $\mathrm{N}$ is made available through mineralization of organic $\mathrm{N}$ during decomposition.

DAYCENT showed a variable pattern in response to changes in precipitation, with clay having higher emission factors for low precipitation, sand showing the opposite response, and loam showing little impact of precipitation. In the model, higher emissions under low precipitation for clay soil results from two factors. Nitrogen availability is higher because crop $\mathrm{N}$ uptake is limited by moisture stress and the model assumes that a significant proportion of soil microsites can remain anoxic with relatively low rainfall in clay soils, thus facilitating denitrification. Sandy soils, on the other hand, require high water inputs to maintain anaerobic conditions and high denitrification rates. A caveat of this kind of model sensitivity analysis is that we used a constant crop rotation to isolate the effects of fertilizer, soil texture, and precipitation, but corn-soy-wheat would not be a common rotation in areas with low precipitation. Consequently, it is probably not appropriate to make general conclusions regarding the impact of rainfall on $\mathrm{N}_{2} \mathrm{O}$ emissions.

\section{DAYCENT Simulations}

National-scale DAYCENT simulations can be divided into two major steps: (i) acquisition and formatting of model driver data, and (ii) conducting model simulations and processing model outputs. The resolution of the simulations is determined by the resolution of available model driver data and of data needed for processing model outputs. The nominal resolution for these simulations was the county level because this was the smallest level at which the National Agricultural Statistics Service (NASS, http://www.nass.usda.gov:8080/QuickStats/, verified 6 Mar. 2006) reported annual (1990-2003) yields and crop area data. Although crop area is not a DAYCENT input, it is necessary to know the area of each crop so that DAYCENT output in units of $\mathrm{g} \mathrm{N}_{2} \mathrm{O}-\mathrm{N} \mathrm{m}^{-2} \mathrm{yr}^{-1}$ can be multiplied by crop area in each county to calculate total annual emissions. Model driver data were selected by identifying the latitude and longitude of the center of the largest cluster of cropped land in each county based on National Land-Cover Data maps (Homer et al., 2004).

\section{DAYCENT Inputs}

Daily maximum and minimum temperature and precipitation were acquired from DAYMET. DAYMET (Thornton et al., 2000, 1997; Thornton and Running, 1999; http://www. daymet.org/, verified 3 Mar. 2006) generates daily surface precipitation, temperature, and other meteorological data using weather station observations and an elevation model. DAYMET climate data is available for the United States at $1-\mathrm{km}^{2}$ resolution for 1980-2001. Climate data from 2001 were also used to represent 2002 and 2003. For each county, DAYMET climate from the $1-\mathrm{km}^{2}$ cell that was closest to the areaweighted geographical center of cropped land was used to drive DAYCENT.

Soil texture data required by DAYCENT were obtained from State Soil Geographic Database (STATSGO, http:// www.ncgc.nrcs.usda.gov/products/datasets/statsgo/, verified 3 Mar. 2006). Hydraulic properties needed for model inputs were calculated from STATSGO surface texture class and Saxton et al.'s (1986) hydraulic properties calculator. For each county, the dominant STATSGO map unit that intersected the area-weighted geographical center of cropped land in that county was used to drive DAYCENT.

Pre-settlement native vegetation was based on the Kuchler (1993) potential natural vegetation map. The dominant native vegetation type in each county was simulated. Land cover and land management data for historical and modern cropping were available at the agricultural-economic region level but not at the county level. The United States is divided into 63 agricultural-economic regions as defined by McCarl et al. (1993). Most states correspond to one of the 63 regions, except some states are divided into two or more regions. Data for region-specific timing and type of cultivation, timing of planting and harvest, and crop rotation schedules were obtained from various sources (USEPA, 2005). Annual county-level crop area data were from the NASS. Reported harvested area was used for alfalfa hay and non-alfalfa hay, but planted area was used for all other crops simulated. In regions where wheat-fallow rotations are the dominant system for wheat cropping, we assumed that county-level fallow area was equal to reported wheat area.

Fertilizer application rates and timing for each of the 63 regions were based on regional, state, or sub-state estimates for different crops using data from various sources (USEPA, 2005). Before 1990, estimates for crop-specific fertilizer rates were based on data for years that were available and on interpolation for years when data were not available. For some crops in some of the 63 regions, little or no data were available, so geographic-based means were used.

To estimate annual fertilizer rates for different crops during 1990-2003, we combined our best estimates for crop-specific fertilizer rates for this time period with yearly national fertilizer production data. Our best estimates of fertilization rates for different crops during 1990-2003 were assumed to represent 1997. This year was chosen as the reference year because that was the only year for which both crop-specific fertilizer and manure amendment rates were available. Fertilizer application rates for years other than 1997 were derived by multiplying 1997 applications by the amount of fertilizer produced in that year relative to the amount produced in 1997, and dividing by the amount of cropped land receiving fertilizer in that year relative to the amount of cropped land receiving fertilizer in 1997. This was done to account for annual fluctuations in the total amount of fertilizer applied and total 
area of cropped land receiving fertilizer. National annual fertilizer production estimates are from fertilizer statistics (USEPA, 2005).

Before 1990, manure application rates and timing for different crops in each region were based on various sources (USEPA, 2005). As with $\mathrm{N}$ fertilizer additions, data for manure were not complete so a proxy was used to fill spatial gaps in data and interpolation was used to fill temporal gaps. Manure $\mathrm{N}$ applied to major cropping systems during 1990-2003 was based on Kellogg et al. (2000), Edmonds et al. (2003), and national managed manure production totals compiled by the USEPA (2005). The data from Kellogg et al. (2000) and Edmonds et al. (2003) are for the year 1997 and the total amount of manure $\mathrm{N}$ accounted for by these authors was less than half of total USEPA (2005) managed manure N production for that year. To account for the managed manure $\mathrm{N}$ that was not applied to soils we subtracted the total manure accounted for by Kellogg et al. (2000) and Edmonds et al. (2003) from total managed manure N (USEPA, 2005) and assumed that this difference was volatilized during transport and storage. This assumption is consistent with estimates of manure ammonia volatilization from Rotz (2004) and Bussink and Oenema (1998). The assumed volatilized manure was included in the calculation for indirect $\mathrm{N}_{2} \mathrm{O}$ emissions. Crop-specific rates for other years were obtained by multiplying the 1997 crop-specific rates by the ratio of managed manure produced in that year to the managed manure produced in 1997. The amount of land receiving manure (approximately 5\% of total cropped land) was assumed to be constant during 1990-2003. Manure was assumed to be applied during spring at the same time as synthetic fertilizer, and synthetic fertilizer rates were reduced by $50 \%$ for cropped land that received organic $\mathrm{N}$ amendments. This assumption is consistent with USDA Economic Research Service (1994) data showing that synthetic fertilizer addition rates are substantially lower in states that have large numbers of dairy cows.

No sewage sludge or other (non-manure) organic fertilizers were assumed to be applied to cropped soils before 1991 . Region-specific application rates in 1997 for sewage sludge and other organic fertilizers were assumed to be equivalent to manure in terms of amounts of $\mathrm{N}$ added per unit area. We assumed that 1997 application rates of sewage sludge $\mathrm{N}$ were identical to manure because there are no data sets of cropspecific application rates for sewage sludge and other organic fertilizers. Amounts of $\mathrm{C}$ added for sludge and other organic fertilizers were calculated according to the ratio of $\mathrm{C}$ to $\mathrm{N}$ in the base material. Crop-specific areas receiving sewage sludge and other organic fertilizers were obtained by dividing the amount of $\mathrm{N}$ applied to cropped soils in the form of sewage sludge and other organic fertilizers by the 1997 crop-specific rates for manure addition. Cropped area receiving sewage sludge and other commercial organic fertilizer amendments (less than $1 \%$ of total cropped land) was assumed to be constant through time. Crop-specific rates for years other than 1997 were obtained by multiplying the 1997 rates by the ratio of sewage sludge or other commercial organic fertilizer produced in that year to the amounts produced in 1997. Estimates of total national annual $\mathrm{N}$ additions from land application of sewage sludge and other organic fertilizers are from the USEPA (2005).

\section{DAYCENT Model Runs and Processing of Outputs}

Three sets of simulations were performed for each county in the United States that reported at least 40 ha of agricultural land: one for the native vegetation (Year 1 to plow-out), one to represent historical agricultural practices (plow-out to 1970), and one for modern agriculture (1971-2003). Plow-out was assumed to occur between 1600 and 1850, depending on the region in which the county lies. Simulations of at least $1600 \mathrm{yr}$ of native vegetation were needed to initialize soil organic matter (SOM) pools in the model and to provide native baseline GHG fluxes to compare with those from agriculture. Simulations of plow-out and historical cropping were needed to establish modern day SOM levels. Proper organic soil carbon simulation is important because $\mathrm{N}_{2} \mathrm{O}$ emissions are sensitive to SOM. These simulations assumed conventional tillage cultivation, gradual improvement of cultivars, and gradual increases in synthetic fertilizer application until 1989. More primitive cultivars (cultivated varieties) were slower growing, had lower yield potentials, and had lower nutrient requirements than modern varieties. Synthetic fertilizer was not added before 1950 and we assumed that this amount was initially small and gradually increased to present-day levels in 1990. Before 1950, for most of the country we simulated multiyear rotations involving corn and/or wheat mixed with pasture and/or hay. The exception to this is the southeastern states, where we assumed that cotton was rotated with corn.

Only one sequence of native vegetation and historical cropping were simulated in each county (Year 1-1970). Our estimates of historical cropping practices (e.g., crop rotations, manure additions) for different regions were based on data from various sources, including government reports, research papers, and texts, which are described in detail in USEPA (2005). The values for state variables from the last year of historical cropping (1970) were saved and used as initial conditions in the set of simulations performed to represent recent modern cropping. Beginning in 1971, up to seven major cropping systems were simulated in each county in which they occur using the same initial (1970) conditions. That is, a single simulation was used to represent each county before 1971, but from 1971-2003 a set of simulations was performed which branched out from the 1970 initial conditions. We define major crops as corn, soy, wheat, alfalfa hay, other hay, sorghum, and cotton. These crops represent approximately $90 \%$ of principal cropped land and $86 \%$ of total cropped land in the United States. Principal crop types, as defined by NASS (USDA, 2003), include all grain, hay, and row crops, as well as vegetables for processing. Total cropped area includes principal crops plus fruit trees, nut trees, and commercial vegetables. All major crops were simulated with and without organic matter amendments. Organic matter amendments include separate simulations for manure, sewage sludge, and other commercial organic fertilizer additions. All crops in all counties were simulated without irrigation except corn, soy, hay, and cotton, which were assumed to be irrigated in states west of the 98th parallel.

For rotations that include a cycle that repeats every two or more years (e.g., corn-soy, wheat-corn-fallow), different simulations were performed where the initial crop was varied but the sequence was not altered. For example, in regions where wheat-corn-fallow cropping is used, three rotations were simulated: one with wheat grown in the first year, a second with corn in the first year, and a third with fallow in the first year. This ensured that each crop was represented during each year. Emissions from cultivated fallow land were also included.

To isolate the anthropogenic portion of direct and indirect $\mathrm{N}_{2} \mathrm{O}$ emissions, simulated direct $\mathrm{N}_{2} \mathrm{O}$ emissions and indirect emissions from $\mathrm{N}$ volatilization and $\mathrm{NO}_{3}$ leaching from the native condition were subtracted from these $\mathrm{N}$ loss vectors for modern cropping for each crop in each county for each year. One simulation of only native vegetation from Year 1 until 2003 was performed to provide annual non-anthropogenic $\mathrm{N}$ losses for 1990-2003. For each crop, four separate sets of 
simulations for modern cropping were performed: (i) to represent the land area that received only synthetic fertilizer $\mathrm{N}$ additions, (ii) to represent the land area that received manure $\mathrm{N}$ additions, (iii) to represent the land area that received sewage sludge $\mathrm{N}$ additions, and (iv) to represent the land area that received other organic matter $\mathrm{N}$ additions. The emissions for non-organic matter amended cropping were multiplied by the non-organic matter amended annual area for that crop. Emissions from separate simulations of organic matter amendments were multiplied by the applicable manured, sludged, or other organically fertilized area for that crop. Emissions for the respective non-organic matter amended and organic matter amended areas were summed to obtain county- and regionallevel totals. Regional-level totals were summed to get national totals for direct soil $\mathrm{N}_{2} \mathrm{O}$ emissions, as well as indirect $\mathrm{N}_{2} \mathrm{O}$ emissions from $\mathrm{N}$ volatilization and leaching/runoff. Approximately $10 \mathrm{~d}$ of computer processing time were required to conduct the simulations and process model outputs using nine nodes (two cpu's each) on the LINUX high performance computing cluster housed at the Natural Resource Ecology Laboratory, Colorado State University.

\section{IPCC Methodology for Non-Major Cropping Systems}

IPCC (1997) guidelines are based solely on annual $\mathrm{N}$ inputs and do not explicitly account for crop areas, except for Histosol cropping. IPCC (1997) guidelines assume that 1.25\% of unvolatilized $\mathrm{N}$ inputs are lost from soil as direct $\mathrm{N}_{2} \mathrm{O}$ emission, $10 \%$ of synthetic fertilizer $\mathrm{N}$ and $20 \%$ of organic fertilizer $\mathrm{N}$ applied is volatilized as $\mathrm{NO}_{x}+\mathrm{NH}_{3}$, and $30 \%$ of applied $\mathrm{N}$ is leached or runs off into ground water or surface waters. Nitrogen inputs for calculating direct $\mathrm{N}_{2} \mathrm{O}$ emission include fertilizer and organic amendments, aboveground biomass $\mathrm{N}$ in $\mathrm{N}$-fixing plants, and plant residue $\mathrm{N}$ that was not removed during harvesting. Nitrogen inputs from fixation and crop residues are based on national totals for crop yields, cropspecific assumptions regarding harvest to residue ratios, and $\mathrm{N}$ concentration of residues. Only $\mathrm{N}$ inputs from synthetic and organic fertilizer are considered to contribute to indirect emissions under IPCC (1997) methodology. Indirect $\mathrm{N}_{2} \mathrm{O}$ emission is defined as the sum of $1 \%$ of $\mathrm{NO}_{x}+\mathrm{NH}_{3}$ gases emitted and $2.5 \%$ of $\mathrm{NO}_{3}$ leached to surface or ground waters. Direct emissions for Histosols are assumed to be $8 \mathrm{~kg} \mathrm{~N}_{2} \mathrm{O}-\mathrm{N}$ ha ${ }^{-1}$ for temperate and $12 \mathrm{~kg} \mathrm{~N}_{2} \mathrm{O}-\mathrm{N} \mathrm{ha}^{-1}$ for subtropical Histosols. Histosols, like $\mathrm{N}$ from crop residues and fixation, are not considered to contribute to indirect emissions under IPCC (1997) guidelines.

A process of elimination approach was used to estimate total fertilizer $\mathrm{N}$ applied to non-major crops. Estimates for $\mathrm{N}$ fertilizer applied to settlements (approximately 10\% of total synthetic fertilizer $\mathrm{N}$ used in the United States) and forest lands (approximately $0.5 \%$ ) were added to the amount of $\mathrm{N}$ fertilizer applied to major crops (70-80\%). This sum was subtracted from total fertilizer consumed in the United States and the difference (10-20\%) was assumed to be applied to nonmajor crops. Estimates of $\mathrm{N}$ applied to forests were based on data from the North Carolina State Forest Nutrition Cooperative (2002) and estimates for $\mathrm{N}$ applied to settlements are from Y. Qian (personnel communication). Nitrogen applied to major crops was based on data from various sources; see USEPA (2005) for details. Nitrogen from organic fertilizers does not need to be included here because all organic matter additions were assumed to be applied to major crops simulated by DAYCENT. Nitrogen in aboveground biomass for $\mathrm{N}$-fixing crops not simulated by DAYCENT was derived from production statistics, crop-specific residue-to-yield mass ratios, and by assuming that the $\mathrm{N}$ content for aboveground biomass of beans and pulses is $3 \%$ (USEPA, 2005). It was assumed that $90 \%$ of residues from oats, rye, millet, peanuts, and other beans and pulses, and $100 \%$ of unburned rice residue is left on the field (USEPA, 2005). Residue $\mathrm{N}$ from non-major crops was derived from production statistics, crop-specific residue-to-yield mass ratios, and crop-specific N content of residue (USEPA, 2005). The IPCC (1997) default emissions factors described earlier were applied to these $\mathrm{N}$ sources and total direct and indirect $\mathrm{N}_{2} \mathrm{O}$ emissions from non-major crops were calculated. Emissions from cultivation of Histosols were based on land area. Estimates of the area of Histosols cultivated in 1982, 1992, and 1997 were obtained from the United States Department of Agriculture's 1997 National Resources Inventory (USDA, 2000). Estimates of areas for other years were calculated using linear interpolation (USEPA, 2005). Areas for temperate and tropical Histosol cultivation were then multiplied by the default IPCC (1997) emission factors described earlier. Emissions from major crops, other crops, and Histosols were summed to obtain total emissions.

\section{RESULTS AND DISCUSSION}

For quality control, DAYCENT simulated countylevel grain and hay yields were compared with yield estimates based on data from the USDA. Because both Census of Agriculture and NASS survey yield data are incomplete, regressions that combined data from both sources were developed to estimate crop yields for 1997 (Erandi Lokupitiya, personal communication). At the county level, the simulated vs. observed regression was favorable for all crops $\left(r^{2}=0.53\right)$. DAYCENT shows a similar pattern for corn yields as the data, but the model tended to underestimate yields in the northeastern states and Arizona, and overestimate yields in some southeastern and Appalachian states (Fig. 2). In contrast to the yield data, DAYCENT output shows discontinuous changes in yield corresponding to state boundaries (Fig. 2). This is a result of the resolution for crop management used in these simulations. Although climate and soils data were available at the county level, crop management was available at the 63-region level, which, in most cases, corresponds to state boundaries. Thus, the amount of fertilizer applied was assumed to be constant within each region but could vary across regions. These model results are limited because only one cultivar for each crop was used throughout the United States, but farmers typically grow cultivars that have appropriate days to maturity requirements based on growing season length for different regions of the country. For these reasons, comparisons of simulated vs. observed yields for individual crops at the county level were not very favorable, with $r^{2}$ values ranging from 0.05 for wheat to 0.27 for alfalfa. More detailed model driver data, particularly for $\mathrm{N}$ inputs, would likely improve simulated yields.

Maps of area-weighted mean (1990-2003) $\mathrm{N}_{2} \mathrm{O}$ emissions, and $\mathrm{NO}_{3}$ leaching were used to ensure that the patterns and rates are reasonable (Fig. 3). The means in Fig. 3 are weighted by the areas of the crops simulated, as well as the area in each county that was assumed to be covered with native vegetation. We assumed that all of the area in each county that is not used for cropping is covered with native vegetation. Nitrous oxide emissions 

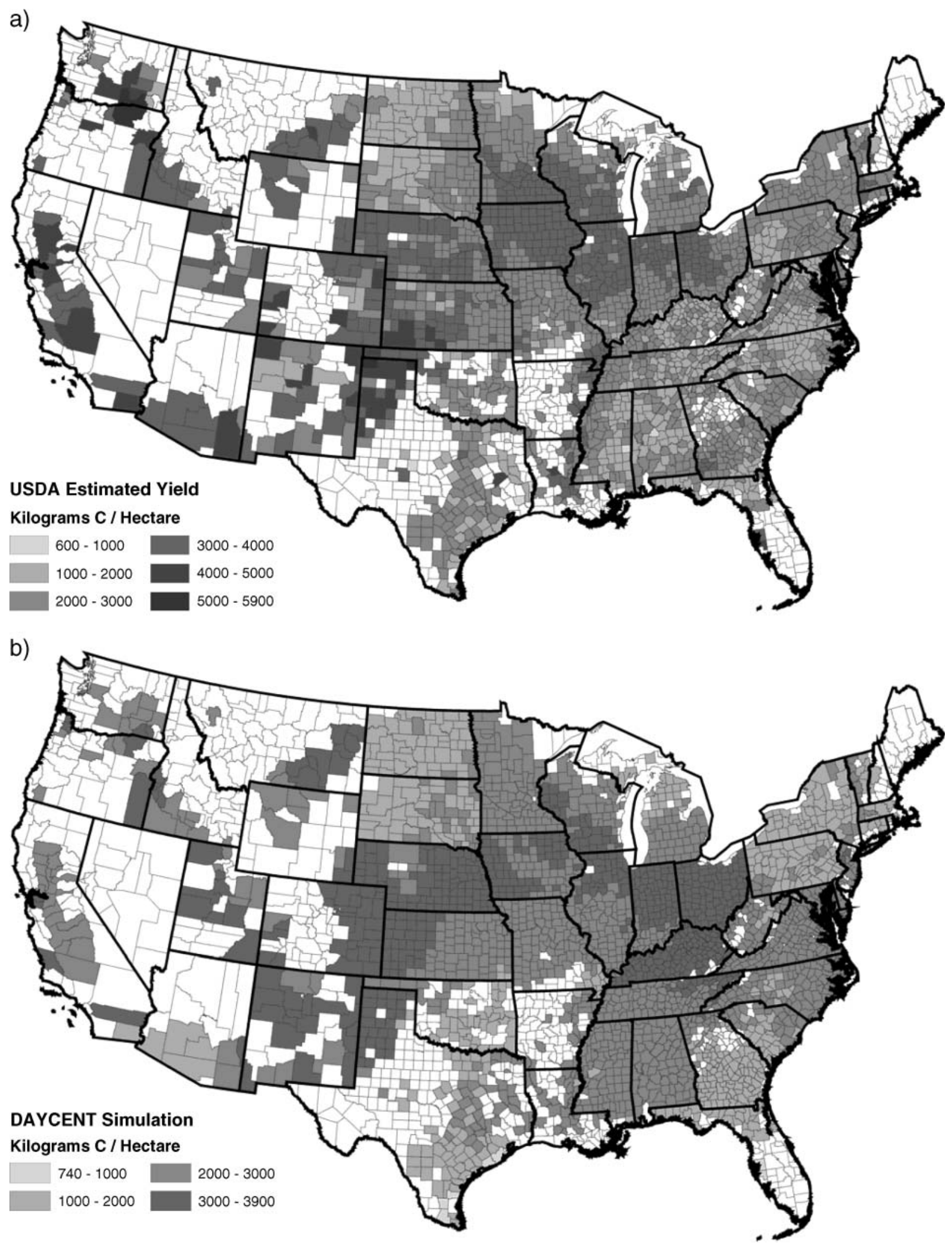

Fig. 2. County-level crop yields based on (a) USDA survey data and (b) DAYCENT simulations for 1997.

are high in the Corn Belt where $\mathrm{N}$ fertilization rates are high and a large portion of the total area is used for agriculture. The Mississippi Valley has some high emissions where the soils tend to be fine textured, which facilitates denitrification. Emissions are low in the southeastern states, where $\mathrm{N}$ addition rates tend to be low and soils are coarser textured, and in the dry western states. 
a)

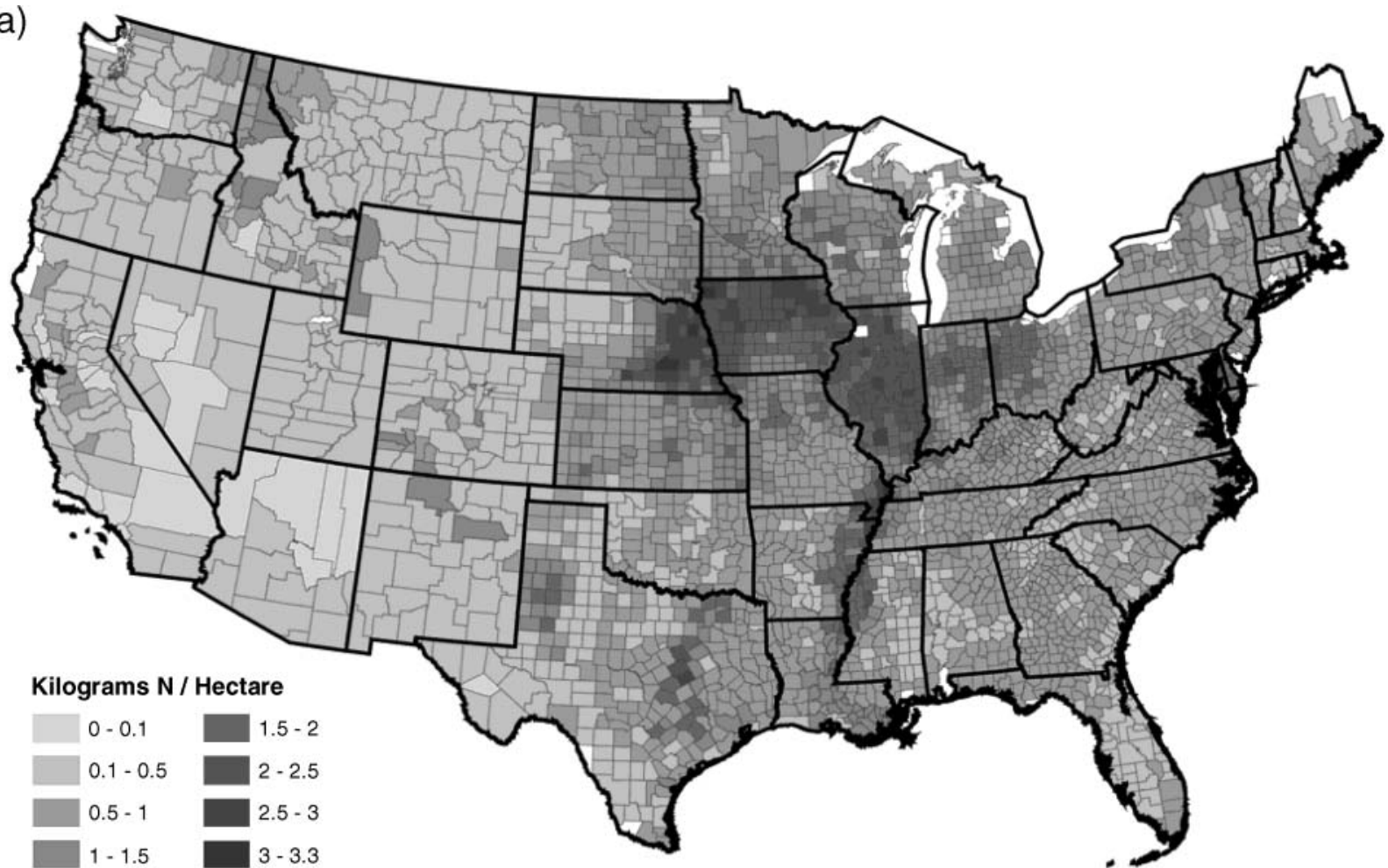

b)

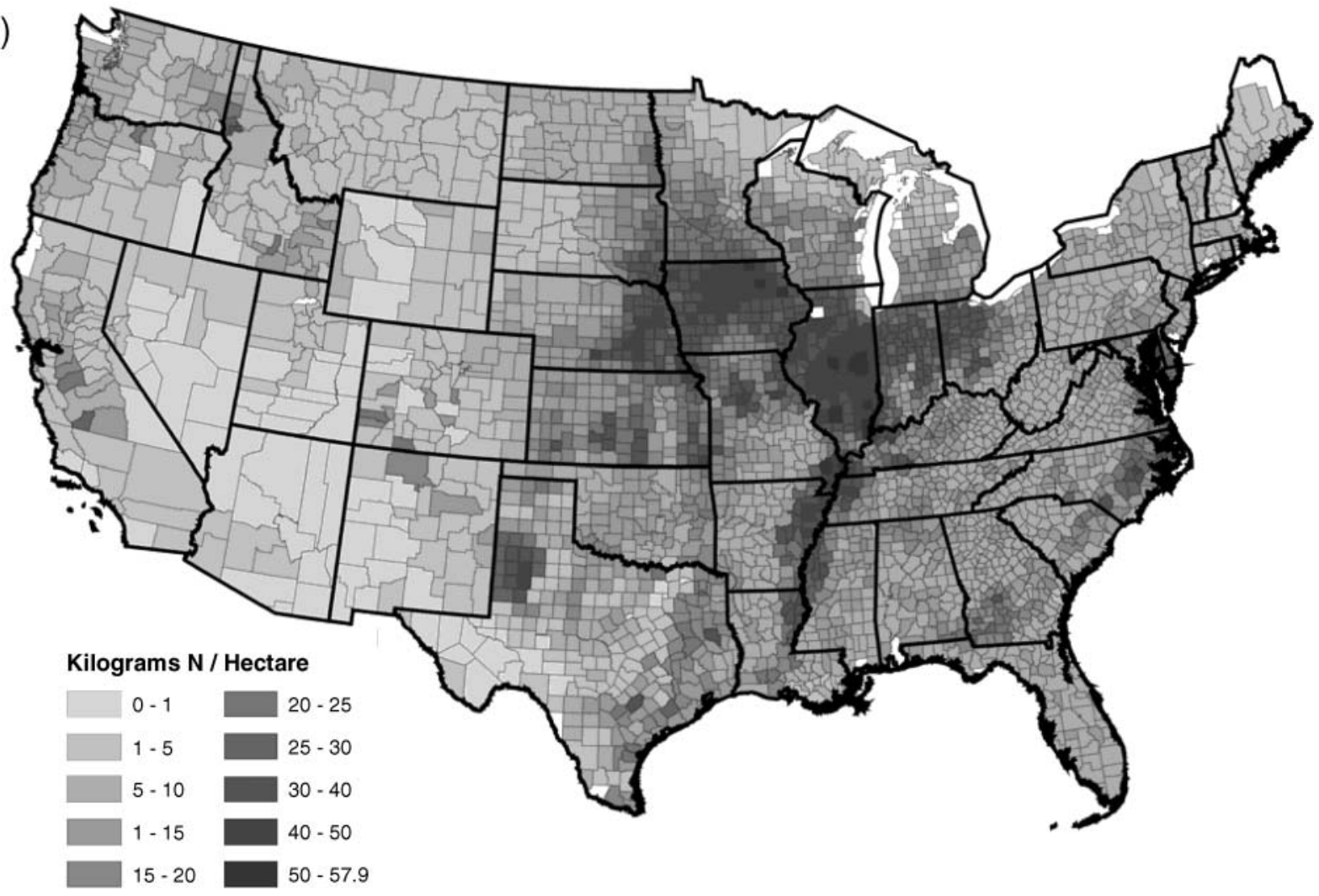

Fig. 3. County-level mean annual soil (a) $\mathrm{N}_{2} \mathrm{O}$ emissions and (b) $\mathrm{NO}_{3}$ leaching simulated by DAYCENT for 1990-2003. 
We compared mean (1990-2003) DAYCENT/IPCC estimated $\mathrm{N}_{2} \mathrm{O}$ emissions with national and state-level emissions estimated using various other models. National direct soil $\mathrm{N}_{2} \mathrm{O}$ emissions estimated by DAYCENT/IPCC were approximately $31 \%$ lower than estimated using only IPCC (1997) methodology. State-level comparisons with the DNDC model (Li et al., 1996) showed general agreement between DAYCENT/IPCC and DNDC for emissions from agricultural soils for most of the central and western United States, but DNDC estimated approximately $50 \%$ higher emissions from the northeastern states and approximately 300\% higher emissions than DAYCENT/IPCC for the southeastern states. One reason for this is that DNDC assumed that fertilizer rates for corn were constant throughout the United States $(150 \mathrm{~kg}$ $\mathrm{N} \mathrm{ha}^{-1}$ ) but the DAYCENT simulations accounted for lower rates of fertilizer inputs in the northeastern and southeastern states compared to the Corn Belt. The DNDC simulations may have overestimated manure $\mathrm{N}$ inputs because they assumed that $50 \%$ of manure produced was applied to cropland, but data from Kellogg et al. (2000), Edmonds et al. (2003), and USEPA (2005) suggest that only about $1 \mathrm{Tg} \mathrm{N}$ out of approximately $7 \mathrm{Tg}$ $\mathrm{N}$ total manure produced annually is applied to crops. Over half of manure $\mathrm{N}$ produced annually (approximately $4 \mathrm{Tg} \mathrm{N}$ ) is classified as unmanaged, meaning it is not transported, stored, or applied to crops (USEPA, 2005). Mummey et al. (1998) also estimated national $\mathrm{N}_{2} \mathrm{O}$ emissions from cropped soils and showed approximately four times lower emissions for the southeastern states than DNDC. National annual total emissions for cropped soils were 500 to $740 \mathrm{Gg} \mathrm{N} \mathrm{N}_{2} \mathrm{O}-\mathrm{N}$ for DNDC, 448 for Mummey et al. (1998), and 439 for DAYCENT/IPCC. The DAYCENT/IPCC results reported here are higher than the DAYCENT/IPCC results reported in USEPA (2005), $353 \mathrm{Gg} \mathrm{N}_{2} \mathrm{O}-\mathrm{N}$, because the latter is meant to represent anthropogenic emissions, obtained by subtracting emissions estimated for native vegetation from emissions estimated for modern agriculture.

Similar to $\mathrm{N}_{2} \mathrm{O}, \mathrm{NO}_{3}$ leaching is highest in the Corn Belt, where $\mathrm{N}$ addition rates tend to be highest (Fig. $3 \mathrm{~b}$ ). Leaching is generally low in the dry areas of the western states and can be high in the southeastern states where soils tend to be coarse textured. Donner and Kucharik (2003) used the IBIS ecosystem model and the HYDRA hydrological transport model to estimate $\mathrm{NO}_{3}$ export across the Upper Mississippi Basin. Donner and Kucharik (2003) include $0.5^{\circ}$ resolution maps of $\mathrm{NO}_{3}$ leaching for the basin and comparison with DAYCENT county-level map for this region showed similar spatial patterns of leaching, but DAYCENT estimates were approximately $75 \%$ higher. Van Drecht et al. (2003) used a global model to estimate the fate of $\mathrm{N}$ at $0.5^{\circ}$ resolution and include estimates for export of $\mathrm{N}$ from the world's major river systems. DAYCENT simulated $\mathrm{NO}_{3}$ leaching for the counties within the Mississippi Basin was 4.6 vs. $1.9 \mathrm{Tg} \mathrm{N}$ for the mouth of the Mississippi. If we assume that $30 \%$ of the $\mathrm{NO}_{3}$ is retained within the river system as suggested by Van Drecht et al. (2003) and that $20 \%$ of the $\mathrm{NO}_{3}$ that enters the river is denitrified, then the DAYCENT estimate is only

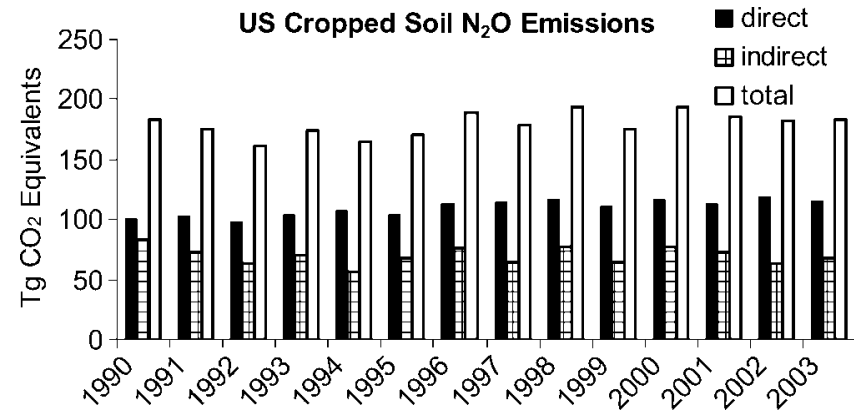

Fig. 4. Time series for annual direct, indirect, and total anthropogenic $\mathrm{N}_{2} \mathrm{O}$ emissions for cropped soils in the United States. Emissions are sums of DAYCENT estimates for major crops and Intergovernmental Panel on Climate Change (IPCC, 1997) estimates for remaining crops and Histosols.

approximately $21 \%$ higher ( 2.3 vs. $1.9 \mathrm{Tg} \mathrm{N})$ than that reported by Van Drecht et al. (2003).

Figure 4 shows national totals for direct, indirect, and total anthropogenic $\mathrm{N}_{2} \mathrm{O}$ emissions from cropped soils for 1990-2003. Given that total fertilizer applied to crops did not change much during 1990-2003 (CV $=3.5 \%)$, a large portion of the variability in annual $\mathrm{N}_{2} \mathrm{O}$ emissions $(\mathrm{CV}=5.5 \%)$ was driven by climate patterns. Total $\mathrm{N}$ additions from fertilizer are important with IPCC (1997) methodology, while DAYCENT accounts for total N additions as well as environmental and management conditions. As a result, simulated $\mathrm{N}_{2} \mathrm{O}$ emission estimates may increase or decrease nonlinearly, whereas emissions always increase linearly with $\mathrm{N}$ applications when using IPCC (1997) methodology. Compared to estimates for the United States based solely on IPCC (1997) methodology, the hybrid approach used here has $31 \%$ lower direct soil $\mathrm{N}_{2} \mathrm{O}$ emissions, $31 \%$ higher indirect emissions, and $12 \%$ lower total emissions from cropped soils. Although the two methodologies predict similar direct emissions from fertilized crops, IPCC (1997) methodology predicts much higher (two to four times) direct emissions than DAYCENT for N-fixing crops (Del Grosso et al., 2005). For alfalfa cropping in Michigan, for example, IPCC (1997) methodology estimated annual $\mathrm{N}_{2} \mathrm{O}$ emissions of approximately $3.8 \mathrm{~kg}$ $\mathrm{N} \mathrm{ha}^{-1}$ while DAYCENT and observations (Robertson et al., 2000) estimated approximately $1.8 \mathrm{~kg} \mathrm{~N} \mathrm{ha}^{-1}$ (Del Grosso et al., 2005). Indirect emissions are higher with the hybrid approach primarily because DAYCENT predicts more $\mathrm{NO}_{3}$ leaching (a component of indirect emissions) than IPCC (1997) methodology, particularly for $\mathrm{N}$-fixing crops (Del Grosso et al., 2005).

\section{FUTURE WORK}

Future model runs for the national $\mathrm{N}_{2} \mathrm{O}$ inventory will include more crops and will simulate both irrigated and non-irrigated land in each county. Model parameterizations will be developed for crops currently not simulated, and parameters for controlling crop growth will be refined. Confidence limits will be quantified using a Monte Carlo approach similar to that developed by Ogle et al. (2003). Sub-county model runs will be performed to analyze model sensitivity to climate and soil 
texture class. That is, instead of using climate from one DAYMET cell and soils data from one STATSGO map unit for all crops within a county, we will use cropspecific climate and soils data based on satellite observations of the area in each county where different crops tend to be grown. We will also attempt to acquire land management data at a finer resolution than the 63-region level. Availability of finer resolution landmanagement data should lead to better agreement between DAYCENT and USDA-estimated county-level yields, which should increase confidence in modelgenerated $\mathrm{N}_{2} \mathrm{O}$ estimates.

\section{ACKNOWLEDGMENTS}

The research for this paper was supported by the USEPA (EPA Project \#TGC04), the National Institute of Child Health and Human Development (\#1 R01 HD33554), the National Science Foundation Long Term Ecological Research project (DEB0217631), and through funds provided by the Cooperative State Research, Education, and Extension Service, USDA (Agreement \#2001-38700-11092) to the Consortium for Agricultural Soils Mitigation of Greenhouse Gases (CASMGS).

\section{REFERENCES}

Bouwman, A.F., L.J.M. Boumans, and N.H. Batjes. 2002a. Modeling global $\mathrm{N}_{2} \mathrm{O}$ and $\mathrm{NO}$ emissions from fertilized fields. Global Biogeochem. Cycles 16, doi:10.1029/2001GB001812.

Bouwman, A.F., L.J.M. Boumans, and N.H. Batjes. 2002b. Emissions of $\mathrm{N}_{2} \mathrm{O}$ and $\mathrm{NO}$ from fertilized fields: Summary of available measurement data. Global Biogeochem. Cycles 16, doi:10.1029/ 2001GB001811.

Bussink, D.W., and O. Oenema. 1998. Ammonia volatilization from dairy farming systems in temperate areas: A review. Nutr. Cycling Agroecosyst. 51:19-33.

Crutzen, P.J. 1981. Atmospheric chemical processes of the oxides of nitrogen including nitrous oxide. p. 17-44. In C.C. Delwiche (ed.) Denitrification, nitrification and atmospheric nitrous oxide. John Wiley \& Sons, New York.

Crutzen, P.J., and D.H. Ehhalt. 1977. Effects of nitrogen fertilizers and combustion on the stratospheric ozone layer. Ambio 6:112-117.

Del Grosso, S.J., A.R. Mosier, W.J. Parton, and D.S. Ojima. 2005. DAYCENT model analysis of past and contemporary soil $\mathrm{N}_{2} \mathrm{O}$ and net greenhouse gas flux for major crops in the USA. Soil Tillage Res. 83:9-24, doi:10.1016/j.still.2005.02.007.

Del Grosso, S.J., D.S. Ojima, W.J. Parton, A.R. Mosier, G.A. Peterson, and D.S. Schimel. 2002. Simulated effects of dryland cropping intensification on soil organic matter and greenhouse gas exchanges using the DAYCENT ecosystem model. Environ. Pollut. 116:S75-S83.

Del Grosso, S.J., W.J. Parton, A.R. Mosier, M.D. Hartman, J. Brenner, D.S. Ojima, and D.S. Schimel. 2001a. Simulated interaction of carbon dynamics and nitrogen trace gas fluxes using the DAYCENT model. p. 303-332. In M. Schaffer et al. (ed.) Modeling carbon and nitrogen dynamics for soil management. CRC Press, Boca Raton, FL.

Del Grosso, S.J., W.J. Parton, A.R. Mosier, M.D. Hartman, C.A. Keough, G.A. Peterson, D.S. Ojima, and D.S. Schimel. 2001b. Simulated effects of land use, soil texture, and precipitation on $\mathrm{N}$ gas emissions using DAYCENT. p. 413-431. In R.F. Follett and J.L. Hatfield (ed.) Nitrogen in the environment: Sources, problems, and management. Elsevier Science Publ., Amsterdam.

Del Grosso, S.J., W.J. Parton, A.R. Mosier, D.S. Ojima, A.E. Kulmala, and S. Phongpan. 2000a. General model for $\mathrm{N}_{2} \mathrm{O}$ and $\mathrm{N}_{2}$ gas emissions from soils due to denitrification. Global Biogeochem. Cycles 14:1045-1060

Del Grosso, S.J., W.J. Parton, A.R. Mosier, D.S. Ojima, C.S. Potter, W. Borken, R. Brumme, K. Butterbach-Bahl, P.M. Crill, K. Dobbie, and K.A. Smith. 2000b. General $\mathrm{CH}_{4}$ oxidation model and com- parisons of $\mathrm{CH}_{4}$ oxidation in natural and managed systems. Global Biogeochem. Cycles 14:999-1019.

Donner, S.D., and C.J. Kucharik. 2003. Evaluating the impacts of land management and climate variability on crop production and nitrate export across the Upper Mississippi Basin. Global Biogeochem. Cycles 17, doi:10.1029/2001GB001808.

Edmonds, L., N. Gollehon, R.L. Kellogg, B. Kintzer, L. Knight, C. Lander, J. Lemunyon, D. Meyer, D.C. Moffitt, and J. Schaeffer. 2003. Costs associated with development and implementation of comprehensive nutrient management plans. Part 1. Nutrient management, land treatment, manure and wastewater handling and storage, and recordkeeping. USDA-NRCS, Washington, DC.

Homer, C., C. Huang, L. Yang, B. Wylie, and M. Coan. 2004. Development of a 2001 National Land-cover Database for the United States. Photogramm. Eng. Remote Sens. 70:829-840.

IPCC. 1997. Intergovernmental Panel on Climate Change guidelines for National Greenhouse Gas Inventories. Chapter 4. Agriculture: Nitrous oxide from agricultural soils and manure management. OECD, Paris.

IPCC. 2001. Intergovernmental Panel on Climate Change technical summary of the 3rd Assessment Report of Working Group 1. IPCC, Geneva.

Kellogg, R.L., C.H. Lander, D.C. Moffitt, and N. Gollehon. 2000. Manure nutrients relative to capacity of cropland and pastureland to assimilate nutrients: Spatial and temporal trends for the United States. USDA Publ. nps00-0579. USDA, Washington, DC.

Khalil, K., B. Mary, and P. Renault. 2004. Nitrous oxide production by nitrification and denitrification in soil aggregates as affected by $\mathrm{O}_{2}$ concentration. Soil Biol. Biochem. 39:687-699.

Kuchler, A.W. 1993. Potential natural vegetation of the conterminous United States. Digital vector data in an Albers Equal Area Conic polygon network and derived raster data on a $5 \mathrm{~km}$ by $5 \mathrm{~km}$ Albers Equal Area 590x940 grid. In Global Ecosystems Database Version 2.0. NOAA Natl. Geophysical Data Center, Boulder, CO.

Li, C., V. Narayanan, and R.C. Harris. 1996. Model estimates of nitrous oxide emissions from agricultural lands in the United States. Global Biogeochem. Cycles 10:297-306.

McCarl, B.A., C.C. Chang, J.D. Atwood, and W.I. Nayda. 1993 Documentation of ASM: The U.S. Agricultural Sector Model. Tech. Rep. TR-93. Agric. Exp. Stn., College Station, TX.

Mosier, A.R., A.D. Halvorson, C.A. Reule, and X.J. Liu. 2006. Net global warming potential and greenhouse gas intensity in irrigated cropping systems in northeastern Colorado. J. Environ. Qual. 35:1584-1598 (this issue).

Mosier, A., and C. Kroeze. 2000. Potential impact on the global atmospheric $\mathrm{N}_{2} \mathrm{O}$ budget of the increased nitrogen input required to meet future global food demands. Chemosphere Global Change Sci. 2:465-474.

Mummey, D.L., J.L. Smith, and G. Bluhm. 1998. Assessment of alternative management practices on $\mathrm{N}_{2} \mathrm{O}$ emissions from US agriculture. Agric. Ecosyst. Environ. 70:79-87.

North Carolina State Forest Nutrition Cooperative. 2002. 31st annual report. Dep. of Forestry, College of Natural Resources, North Carolina State Univ., Raleigh.

Ogle, S.M., F.J. Breidt, M.D. Eve, and K. Paustian. 2003. Uncertainty in estimating land use and management impacts on soil organic carbon storage for US agricultural lands between 1982 and 1997. Global Change Biol. 9:1521-1542.

Parton, W.J., M.D. Hartman, D.S. Ojima, and D.S. Schimel. 1998 DAYCENT: Its land surface submodel: Description and testing. Global Planet. Change 19:35-48.

Parton, W.J., E.A. Holland, S.J. Del Grosso, M.D. Hartman, R.E. Martin, A.R. Mosier, D.S. Ojima, and D.S. Schimel. 2001. Generalized model for $\mathrm{NO}_{\mathrm{x}}$ and $\mathrm{N}_{2} \mathrm{O}$ emissions from soils. J. Geophys. Res. 106(D15):17403-17420.

Parton, W.J., D.S. Ojima, C.V. Cole, and D.S. Schimel. 1994. A general model for soil organic matter dynamics: Sensitivity to litter chemistry, texture and management. p. 147-167. In R.B. Bryant and R.W. Arnold (ed.) Quantitative modeling of soil forming processes. SSSA, Madison, WI.

Robertson, G.P., E.A. Paul, and R.R. Harwood. 2000. Greenhouse gases in intensive agriculture: Contributions of individual gases to the radiative forcing of the atmosphere. Science 289:1922-1925. 
Rotz, C.A. 2004. Management to reduce nitrogen losses in animal production. J. Anim. Sci. 82:E119-E137.

Saxton, K.E., W.J. Rawls, J.S. Romberger, and R.I. Papendick. 1986. Estimating generalized soil-water characteristics from texture. Soil Sci. Soc. Am. J. 50:1031-1036.

Thornton, F.C., and R.J. Valente. 1996. Soil emissions of nitric oxide and nitrous oxide from no-till corn. Soil Sci. Soc. Am. J. 60: $1127-1133$.

Thornton, P.E., H. Hasenauer, and M.A. White. 2000. Simultaneous estimation of daily solar radiation and humidity from observed temperature and precipitation: An application over complex terrain in Austria. Agric. For. Meteorol. 104:255-271.

Thornton, P.E., and S.W. Running. 1999. An improved algorithm for estimating incident daily solar radiation from measurements of temperature, humidity, and precipitation. Agric. For. Meteorol. 93: 211-228.
Thornton, P.E., S.W. Running, and M.A. White. 1997. Generating surfaces of daily meteorology variables over large regions of complex terrain. J. Hydrol. 190:214-251.

USDA. 2000. 1997 National Resources Inventory. Available at http:// www.nrcs.usda.gov/technical/NRI/ (verified 3 Mar. 2006). USDANRCS, Washington, DC.

USDA. 2003. Agricultural Statistics 2003. U.S. Gov. Print. Office, Washington, DC.

USDA Economic Research Service. 1994. Fertilizer use and price statistics. Stock \#86012. USDA-ERS, Washington, DC.

USEPA. 2005. Inventory of U.S. greenhouse gas emissions and sinks: 1990-2003. USEPA, Washington, DC.

Van Drecht, G., A.F. Bouwman, J.M. Knoop, A.H.W. Beusen, and C.R. Meinardi. 2003. Global modeling of the fate of nitrogen from point and nonpoint sources in soils, groundwater, and surface water. Global Biogeochem. Cycles 17, doi:10.1029/2003GB002060. 